\title{
Rill Hydraulics - An Experimental Study on Gully Basin in Lateritic Upland of Paschim Medinipur, West Bengal, India
}

\author{
Pravat Kumar Shit ${ }^{1} \&$ Ramkrishna Maiti ${ }^{1}$ \\ ${ }^{1}$ Department of Geography and Environment Management, Vidyasagar University, Medinipur, India \\ Correspondence: Pravat Kumar Shit, Department of Geography and Environment Management, Vidyasagar \\ University, Medinipur 721102, West Bengal, India. E-mail: pravatgeo2007@gmail.com
}

Received: February 17, $2012 \quad$ Accepted: March 16, $2012 \quad$ Online Published: August 31, 2012
doi:10.5539/jgg.v4n4p1
URL: http://dx.doi.org/10.5539/jgg.v4n4p1

\begin{abstract}
This paper reports the results of field investigations aimed to establish relationship between morphologic and hydraulic characteristics of rills. A rill network within a small Rangamati Gully Basin, on the bank of Kansai at Paschim Medinipur, in West Bengal, India of $256 \mathrm{~m}^{2}$ was mapped. Experimental basin is exposed to natural rainfall of varying intensity and characterised with an average of 25-35\% slope gradient. The depth, length, gradient, width, runoff contributing areas of all the 33 rills within the basin were recorded and thoroughly mapped. Present study incorporates close monitoring of runoff and velocity along the channels during a storm on 31.08.2010 at 15 minutes interval using dye tracer technique. The velocity along each rill was linked with gradient, width-depth ratio and Manning's roughness coefficient. Analysis shows that flow velocity is not directly controlled by rill gradient $\left(\mathrm{R}^{2}=0.15\right)$, but is influenced by hydraulic roughness coefficient $\left(\mathrm{R}^{2}=0.53\right)$. Finally, the relationship between Reynolds number and Froude number reveals that sub-critical turbulent flow is responsible for rilling process. No significant relationship between W/D ratio and channel roughness (n) can be established $\left(\mathrm{R}^{2}=0.083\right)$ by the present study.
\end{abstract}

Keywords: rills morphology, rills hydraulics, roughness coefficient, velocity

\section{Introduction}

Rills are an integral part of the runoff system of many environments. Rills are small, ephemeral concentrated flow paths which function as both sediment source and sediment delivery systems on upland area. Hydraulic and geomorphic factors of rills are important for understanding the mechanism of rills formation, and spatial as well as temporal variation of geometric characteristics. The geomorphic factors influencing the location and geometry of rills are also related to the variability of soil properties and the landscape (Mancilla et al., 2005). The geomorphic factors reveal that rill initiations are affected by the flow, the roughness of the soil surface, the slope gradient, and the erodibility of the soil (Van et al., 1983; Foster et al., 1984; Bryan et al., 1989; Gilley et al., 1990; Slattery et al., 1992; Obiechefu et al., 1994; Favis-Mortlock et al., 2000).

On the other hand, the hydraulic factors consider flow-related parameters. Flow depths in rills are typically of the order of a centimeter or less on steeper slopes. These conditions constitute a very different hydraulic environment that typically found in channels of streams and rivers (Nearing et al., 1997). No widely accepted formula exists to represent the relationship of discharge, flow velocity and gradient. The flow velocities in rills were developed in loose, non-layered materials depending on flow discharge, while bed slope and hydraulic roughness are irrelevant (Nearing et al., 1997; Govers, 1992; Nearing et al., 1999). Gimenez and Govers (2001) also showed the slope independence of rill flow velocity by identifying feedback mechanism between rill bed roughness and flow hydraulics. On the contrary, the mean flow velocities appeared to depend on both flow discharge and slope of the rill (Foster et al., 1984; Abrahams \& Li, 1996). Yet, for situations where a rill is able to adjust freely its geometry to the flow condition impact of slope on flow velocity becomes insignificant (Takken \& Govers, 1998). Later, Gimenez and Govers (2000) showed that runoff velocity depends on slope when the flow is not capable of eroding the rill channel.

Width-discharge relationship may be extended to channels as small as rills and gullies (Nachtergaele et al., 2002). Torri et al. (2006) established width-discharge relationship for rills and ephemeral gullies on arable land that shows variable discharge exponent depending on rill width. Savenije (2003) stated that the power relationship 
between discharge and channel width is theoretically derivable for the case of bankfull discharge and may be applied to rills and gullies at episodic bankfull discharge condition.
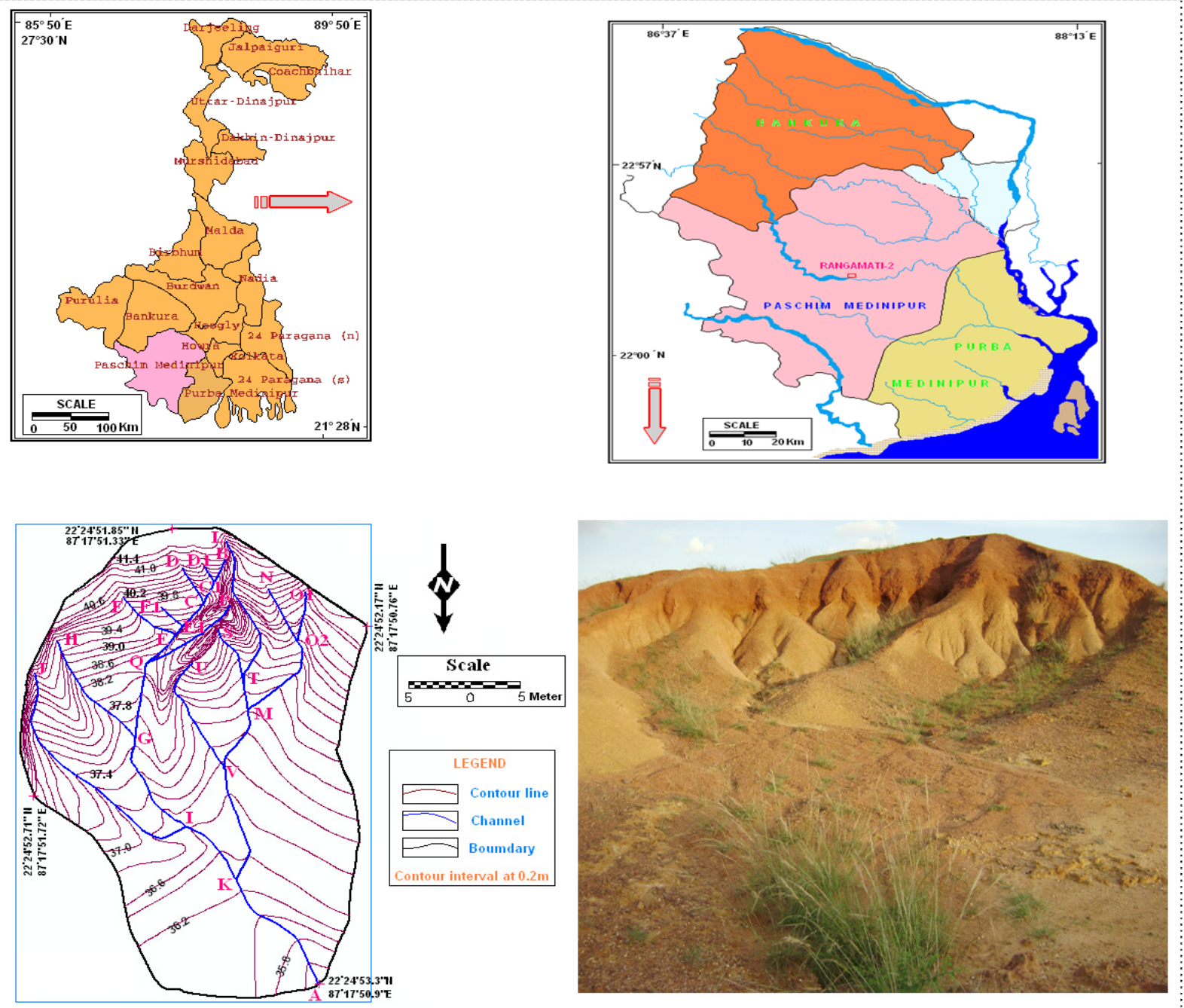

Figure 1 . The study area

Various studies have investigated of the hydraulic roughness of rills. Chow (1959) and Savat (1980) studied the flume experiments on rill; the results indicate a progressive decrease in hydraulic roughness (n) with increased Reynolds number (Rn). In a case, if depth of water is less than the size of the physical roughness coefficient, then Mannings Roughness coefficient increases in correspondence with increase in Rn values (Govers, 1992; Abrahams et al., 1986; Abrahams \& Parsons, 1994; Gilley et al., 1992; Prosser \& Dietrich, 1995). The spatial variability of rilling process depends on flow character controlled by channel roughness and expressed as Reynolds number (Rn) and Froude number (Nearing et al., 1997).

However, the hydraulic considerations must involve flow velocity, which is a key factor of the energy needed for rill development and soil erosion (Mancilla et al., 2005). Flow velocity has been directly related to rill formation and development (Lei et al., 1998) and leads to variable rates of soil loss (Nearing et al., 1999; Mancilla, 2001). Rill flow velocity has been also related to the transport capacity of the flow regime and thus to sediment delivery (Lei et al., 1998; Mancilla, 2001). In particular, rill morphology at a given time is associated to hydraulic roughness features, rills width, and rills depth which are functions of the eroding material, runoff rate, and prior rill structure. Erosion creates the morphology of a rill channel and in turn the rill structure influences the erosion (Nearing et al., 1997). 
Present research focused on rill morphology and its hydraulic characters in lateritic upland area as limited research has been done on this specific field. Specific objectives of this paper were: (1) to establish relative importance of either roughness coefficient, slope gradient and width-depth ratio to control flow velocity and (2) to identify the hydraulic regimes through relationship of Froude numbers and Reynolds numbers in the present situation of rill-gully development.

\section{Study Area}

The study area covers an area of about $256 \mathrm{sq} \mathrm{m}$ and is bounded by $22^{\circ} 24^{\prime} 42.0^{\prime \prime}$ to $22^{\circ} 24^{\prime} 43.2$ "N latitude and $87^{\circ} 17^{\prime} 48.1^{\prime \prime}$ to $87^{\circ} 17^{\prime} 48.09^{\prime \prime}$ E longitude (Figure 1). Total network of the basin is composed of 33 rill links and are marked with certain identity. These rills are classified following Strahler (1964) ordering scheme (Figure 2). A tropical, monsoonal climate prevails in, with mean annual temperature of around $28.4^{\circ} \mathrm{C}$, and average summer (May) and minimum winter (December) temperatures of $40.9^{\circ} \mathrm{C}$ and $7.5^{\circ} \mathrm{C}$ respectively. Mean annual rainfall is about $1850 \mathrm{~mm}$. Rainfall distribution is irregular, experiencing high-intensity rainstorms during June to September. Erosive potential of rain is very high where the rainfall erosivity factor $(R)$ varies between 1200 and $1500 \mathrm{MJ} \mathrm{mm} \mathrm{ha}{ }^{-1} \mathrm{~h}^{-1}$ year $^{-1}$. The soil is lateritic in type having sandy loamy characters with a weak geological formation consisting of Tertiary to early Quaternary unconsolidated sandstones (Shit \& Maiti, 2008).

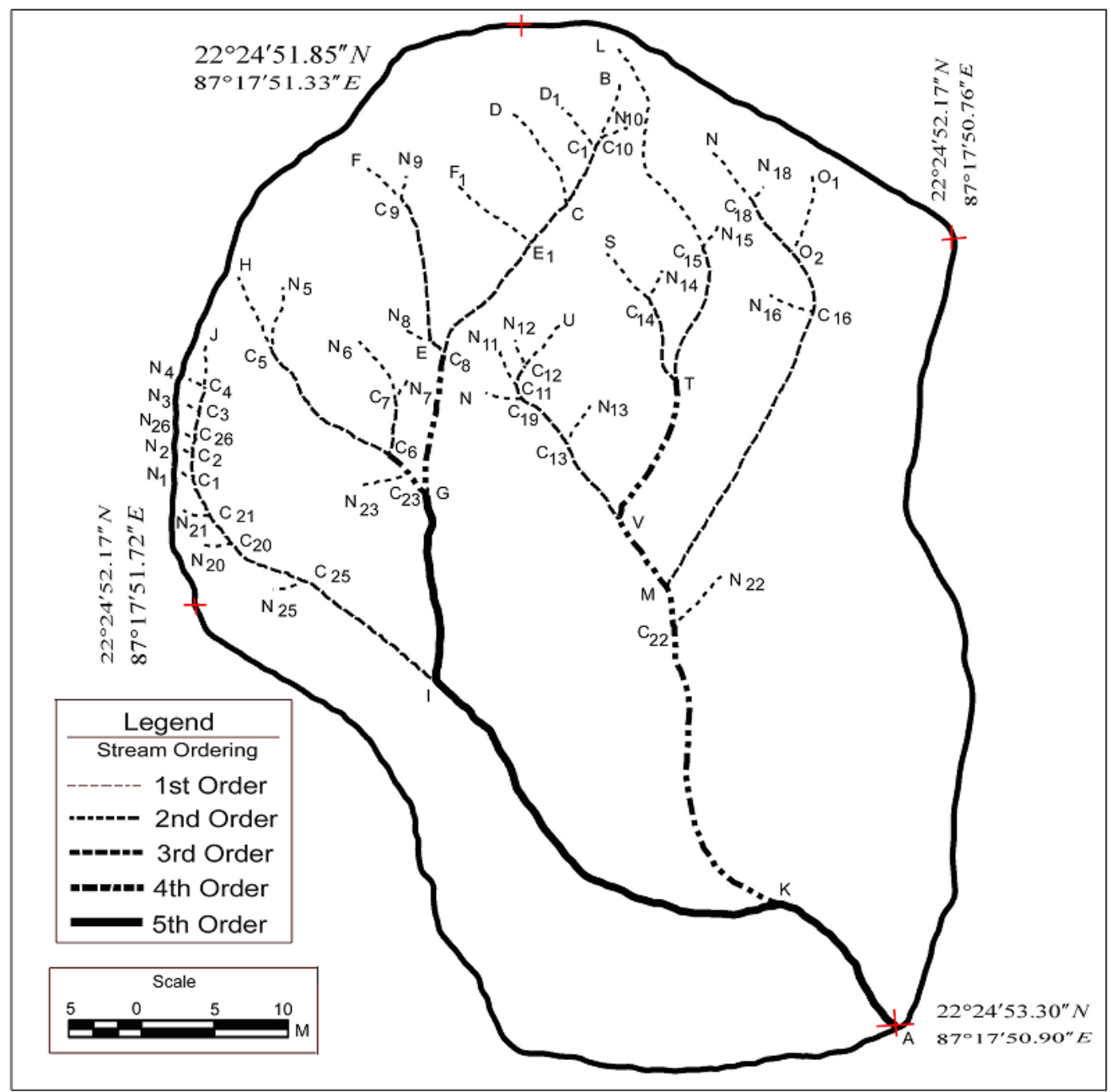

Figure 2. Rill networks with nomenclature identity and Hierarchical Order of Gully Basin

One of the main characteristics of the area is the dissection of the landscape by a dense and deep network of rills and gullies. Inter-gully areas are usually undulating and rolling. The average slope of this area is between $25 \%$ and $35 \%$. The most frequent landforms are complex slopes and gullies. The rills are characterized by vertical sidewalls of 7-13 cm and are $90 \mathrm{~cm}$ wide on an average. Rill has a high degree of lateral as well as head retreat. The nick points, developed at the vertical head near the source, sometimes shows the tension cracks for toppling, 
where centre of gravity overlies the centre of mass (Shit \& Maiti, 2008). Sediment, mobilized from the walls and vertical heads, is usually removed by flowing water during high intensity rainstorms. In other cases, the sediments are deposited on the base of walls or on the gully bottom, which may lead to some degree of stabilization.

\section{Materials and Method}

\subsection{Monitoring Networks}

33 rills under a gully basin are monitored to study morphological and hydrological attributes like rill length (RL), gradient (S), width (W), depth (D), runoff contributing area (RCA), velocity (v), and discharge (Q) with appropriate field techniques (Figure 3). The gradients (S) of the channels were measured with clinometers. The junctions were mapped and attributed with identity for recording hydrological and morphological parameters of the links connecting those nodal points. Longitudinal profile and gully cross-sections were monitored after peak rain intensity. Runoff contributing area for each tributary rill is identified from detailed contour map prepared at $0.1 \mathrm{~m}$ interval. Width, depth and lengths are monitored at each junction with pegging techniques.
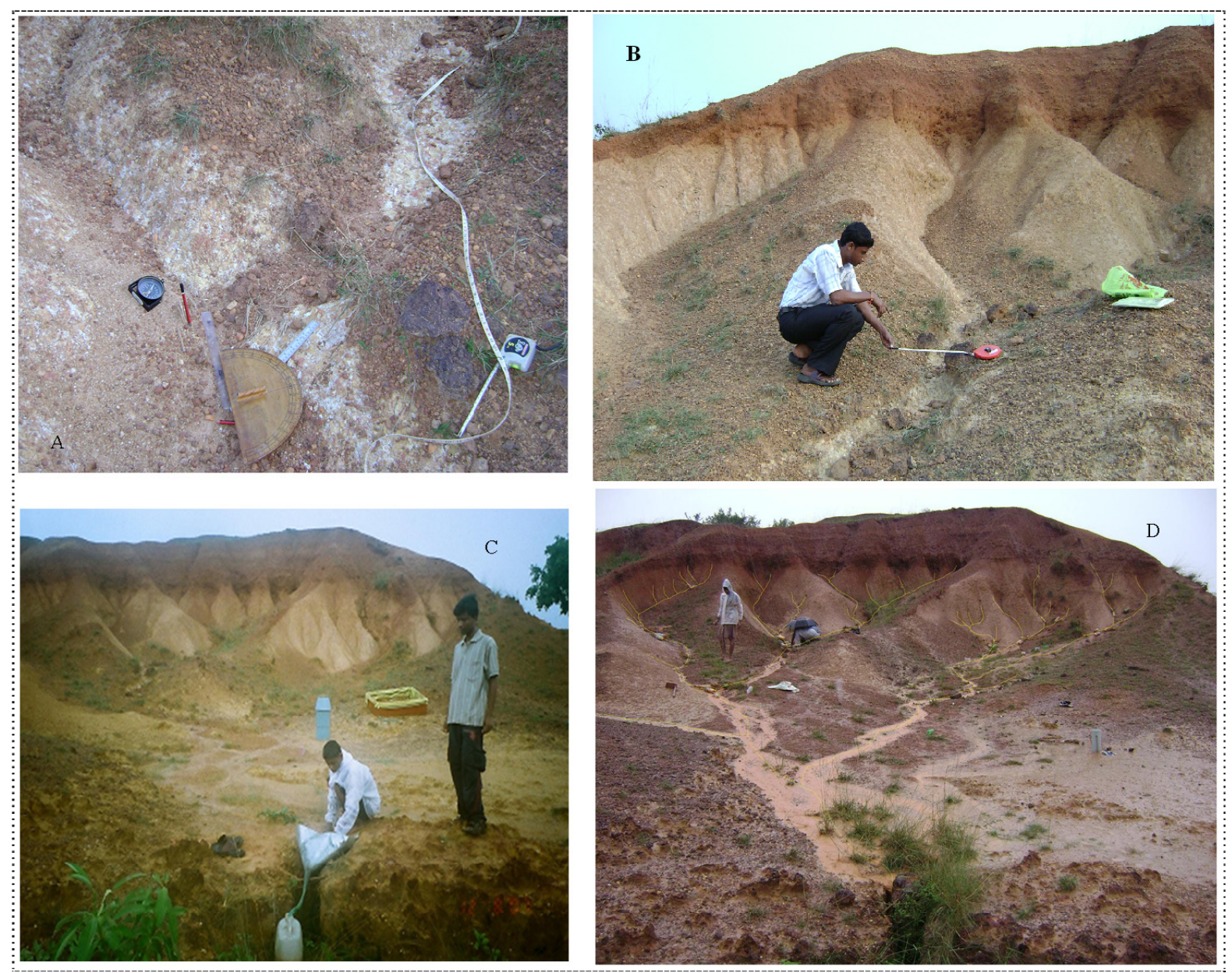

Figure 3. Measurement of Width, Depth, Gradient and Surface Runoff in Gully Basin during study period

\subsection{Runoff and Velocity Measurements}

The experimental methodology involved collection of surface runoff by ' $\mathrm{V}$ ' flume using bottle at each junction points of the gully basin. Rainfall was measured by self recoding rain gauge during the monitoring period following Jehangir and Zokaib (2000) and Zokaib et al. (2005). The average flow velocity was measured in individual rill using a dye-tracing technique following Abrahams et al. (1986), Gilley et al. (1990) and Govers $(1991,1992)$. Potassium permanganate solution was used as a dye, where a small amount of which was injected at the source of the links. Flow velocities were then measured by recording the travel time of the dye cloud over 
the distance of link length. The average travels time was taken as the mean of five measurements (Finkner \& Gilley, 1988).

In any erosion experiment involving rills, it is important to characterize the flow (Polyakov \& Nearing, 2003). We calculated the nondimensional Reynold's and Froude numbers for these experiments. Reynold's number is calculated as the ratio of flow velocity multiplied by hydraulic radius to the kinematic viscosity of water. It is essentially a ratio of kinetic to viscous forces of the flow. Froude number is the ratio of flow velocity to the square root of flow depth multiplied by the gravitational constant. It represents a ratio of kinetic to gravitational flow forces. Depth of flow during target storms is measured in the field directly. Manning's roughness coefficient was calculated for each segment of rills using measured velocity; hydraulic radius (depth of flow) and gradient.

\section{Results and Discussion}

Rainfall received during 10:43 am to $2: 13 \mathrm{pm}$ on 31.08 .2010 was monitored with a self recording rain gauge at 15 minutes interval. Maximum intensity of $4.5 \mathrm{~mm} \mathrm{~h}^{-1}$ was recorded at 12:28 pm after 1:45 hrs of initiation of rain. A maximum of $5.6 \mathrm{Ls}^{-1}$ discharge was collected from the entire catchment after 30 minutes of peak rain (Figure 4). The hydrologic and geomorphic response to this rainfall stimuli is monitored in the present work .The velocity of runoff along the channels, monitored by dye tracer, were linked with width-depth, and roughness coefficients for the present situation. Manning coefficient is a good indicator of hydraulic roughness (Gilley et al., 1990; Nearing et al., 1997) and analysis shows that this roughness tends to decrease flow velocity. Gradient and hydraulic radii are considered as important factors of channel roughness and both are the result of distribution of materials with in channel system. Flow velocity increases with decreasing manning are roughness value (Figures 7 and 8 ). The correlation between these two attributes is moderately strong $\left(\mathrm{R}^{2}=0.5389\right)$, (Figure 5), because the manning's equation has its maximum usefulness in bank full discharge (Savenije 2003; Sanchis et al., 2009). In the present study under the target storm, flow depth was not sufficient for bank full condition. Although channel slope is considered as an important factor of hydraulic roughness, flow velocity in small rills are proved to be independed of gradient (Gimenez \& Govers, 2001; Govers et al., 2007). Slope does not influence the velocity of eroding rill because bed roughness increase with erosion, counterbalancing the expected effect of slope on flow velocity (Figures 6, 7 and 8) (Gilley et al., 1990).

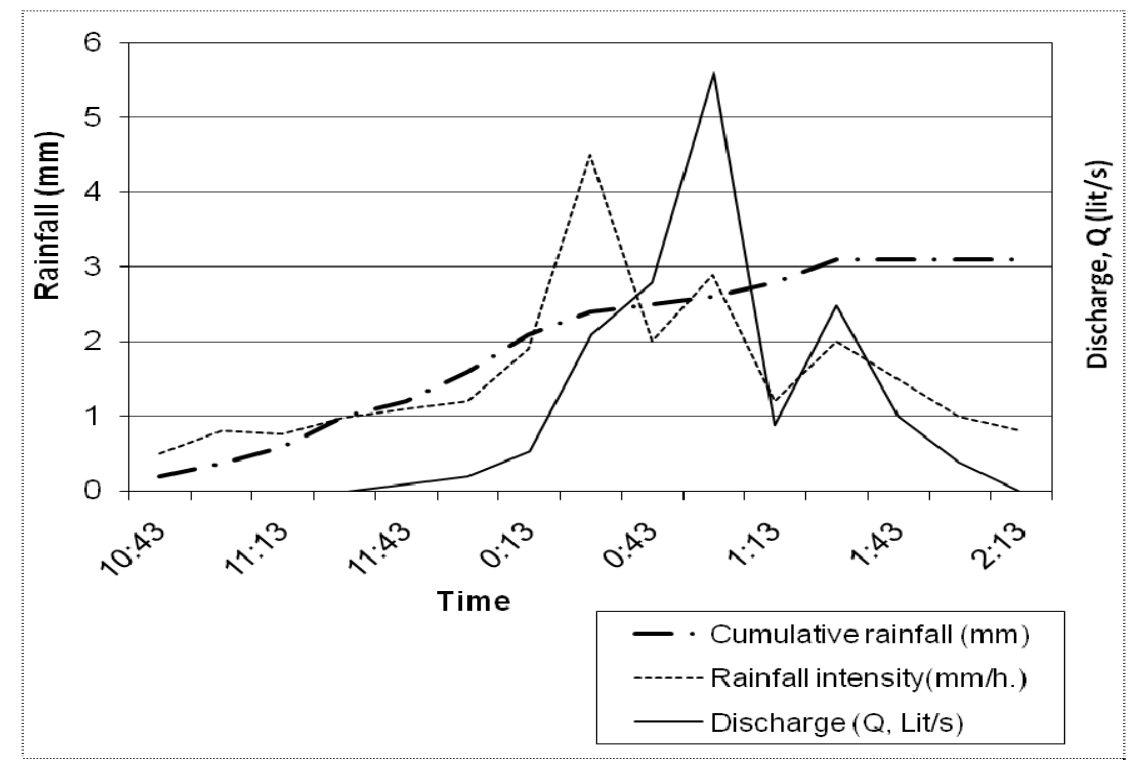

Figure 4. Rainfall and resultant runoff from target storm (date-31.08.2010) of the entire gully basin

In the present study, relations between gradient and channel runoff velocity, and that between width-depth ratio and velocity are found to be insignificant (Figure 5; Table 1). Manning's roughness coefficients are proved to be important for predicting runoff velocities (Nearing et al., 1997), and for constructing runoff hydrograph, lagtime calculation and analyzing runoff of upland areas (Poesen et al., 2003). The Reynold's number ranged between 300 and 61138 and Froude number varied from 0.02468 to 0.487169 . Most of the data represent subcritical 
turbulent hydraulic regime (Figure 9). The correlation between W/D ratio and flow velocity seems to be insignificant in present condition. Bunte and Poesen (1993) showed that on surface with roughness elements, localized turbulence remained present and remained active in causing scour under the condition when Reynold's number varies above 250 (Nearing et al., 1997; 1999).

Sediment concentration was linked with runoff contributing area, but no significant relation was established. Sediment supply to the outlet depends mainly on the local factors like, discharge and localized slope failure and erosion potentials. However, total runoff of each rill has significant relation with runoff contributing areas. Visual observation of the sediment in the rill suggests that the bedload moves in the shallow flow by rolling along the bed, a process that, in either turbulent or laminar flow. In present analysis, by associating Reynold's Number against Froude Number, it is revealed that sub-critical turbulent flow is dominant along the channels (i.e. rills).
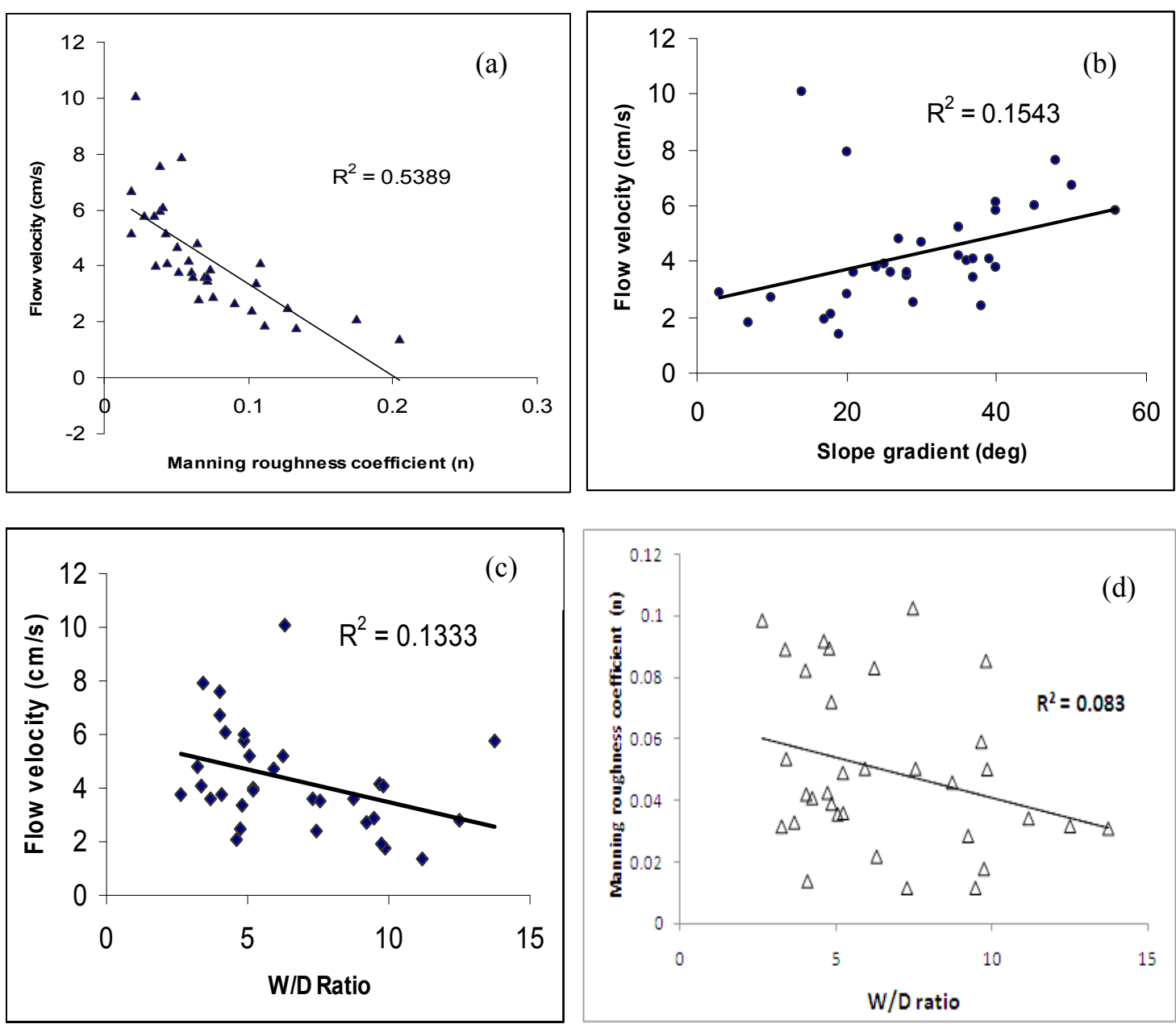

Figure 5. Relationship of flow velocity with (a) Manning roughness coefficient (n), (b) slope gradient, (c) W/D ratio, and (d) correlation between Manning roughness coefficient (n) and W/D ratio 
Table 1. Hydro-geomorphic characteristics of rill network in Rangamati gully catchment area (Data Source: Author's Field Survey, 2009-2010)

\begin{tabular}{|c|c|c|c|c|c|c|c|c|c|c|c|}
\hline Name & $\begin{array}{l}\text { Length } \\
(\mathrm{m})\end{array}$ & $\begin{array}{l}\text { Average } \\
\text { Gradients } \\
\text { (Degree) }\end{array}$ & $\begin{array}{l}\text { Average } \\
\text { Width } \\
\text { (cm) }\end{array}$ & $\begin{array}{l}\text { Average } \\
\text { Depth in } \\
\mathrm{cm}\end{array}$ & $\begin{array}{l}\text { Micro } \\
\text { relief } \\
\text { in } \\
(\mathrm{cm})\end{array}$ & $\begin{array}{l}\mathrm{RCA} \\
\left(\mathrm{m}^{2}\right)\end{array}$ & $\begin{array}{l}\text { Width / } \\
\text { Depth } \\
\text { ratio }\end{array}$ & $\begin{array}{c}\text { Flow } \\
\text { velocity } \\
(\mathrm{cm} / \mathrm{s})\end{array}$ & $\begin{array}{l}\text { Roughness } \\
\text { Coefficient } \\
\text { (Manning) }\end{array}$ & $\begin{array}{l}\text { Froude } \\
\text { Number }\end{array}$ & $\begin{array}{l}\text { Reynolds } \\
\text { Number }\end{array}$ \\
\hline $\mathrm{C}_{20} \mathrm{~N}_{20}$ & 0.6 & 36 & 7 & 1.34 & 39 & 1.687 & 5.223881 & 4 & 0.03576 & 0.110325 & 2680 \\
\hline $\mathrm{C}_{21} \mathrm{~N}_{21}$ & 0.7 & 56 & 8 & 1.65 & 76 & 0.360 & 4.848485 & 5.8 & 0.071869 & 0.069596 & 2310 \\
\hline $\mathrm{C}_{1} \mathrm{~N}_{1}$ & 1.0 & 40 & 9 & 3.42 & 64 & 0.135 & 2.631579 & 3.8 & 0.098321 & 0.034529 & 1420 \\
\hline $\mathrm{C}_{2} \mathrm{~N}_{2}$ & 0.8 & 45 & 13 & 2.68 & 45 & 0.090 & 4.850746 & 6 & 0.038778 & 0.117017 & 8040 \\
\hline $\mathrm{C}_{3} \mathrm{~N}_{3}$ & 0.9 & 50 & 12 & 2.97 & 43 & 0.157 & 4.040404 & 6.7 & 0.041817 & 0.055579 & 1440 \\
\hline $\mathrm{C}_{4} \mathrm{~N}_{4}$ & 0.85 & 35 & 15 & 2.41 & 35 & 0.203 & 6.224066 & 5.2 & 0.082869 & 0.02468 & 300 \\
\hline $\mathrm{IJ}$ & 10.65 & 14 & 16 & 2.54 & 186 & 59.89 & 6.299213 & 10.1 & 0.021692 & 0.202335 & 12827 \\
\hline GH & 5.6 & 25 & 18 & 3.45 & 150 & 16.51 & 5.217391 & 3.9 & 0.048837 & 0.101416 & 10177 \\
\hline $\mathrm{C}_{23} \mathrm{~N}_{23}$ & 1.3 & 26 & 9 & 2.46 & 79 & 2.025 & 3.658537 & 3.6 & 0.032784 & 0.154708 & 9348 \\
\hline $\mathrm{C}_{6} \mathrm{~N}_{6}$ & 3.35 & 27 & 12 & 3.69 & 86 & 3.577 & 3.252033 & 4.8 & 0.031411 & 0.162884 & 18081 \\
\hline $\mathrm{C}_{7} \mathrm{~N}_{7}$ & 0.87 & 35 & 10 & 1.98 & 59 & 0.383 & 5.050505 & 5.2 & 0.03541 & 0.140677 & 61138 \\
\hline $\mathrm{C}_{5} \mathrm{~N}_{5}$ & 1.16 & 40 & 8 & 1.89 & 34 & 1.867 & 4.232804 & 6.1 & 0.040641 & 0.141666 & 5764 \\
\hline $\mathrm{C}_{8} \mathrm{~N}_{8}$ & 1.25 & 24 & 10 & 2.45 & 28 & 2.835 & 4.081633 & 3.8 & 0.013652 & 0.342682 & 20580 \\
\hline $\mathrm{EF}$ & 3.30 & 18 & 17 & 3.69 & 157 & 8.393 & 4.607046 & 2.1 & 0.091585 & 0.066483 & 7380 \\
\hline $\mathrm{C}_{9} \mathrm{~N}_{9}$ & 0.70 & 40 & 14 & 1.02 & 46 & 0.315 & 13.72549 & 5.8 & 0.03076 & 0.164387 & 2652 \\
\hline $\mathrm{E}_{1} \mathrm{~F}_{1}$ & 2.0 & 21 & 12 & 1.65 & 89 & 4.387 & 7.272727 & 3.6 & 0.011401 & 0.487169 & 16170 \\
\hline $\mathrm{CD}$ & 1.80 & 19 & 21 & 1.88 & 97 & 5.435 & 11.17021 & 1.4 & 0.03406 & 0.195599 & 7896 \\
\hline $\mathrm{C}_{1} \mathrm{D}_{1}$ & 1.05 & 35 & 14 & 1.45 & 82 & 2.407 & 9.655172 & 4.2 & 0.058946 & 0.11136 & 3045 \\
\hline $\mathrm{C}_{10} \mathrm{~N}_{10}$ & 1.10 & 37 & 10 & 2.97 & 56 & 0.202 & 3.367003 & 4.1 & 0.088919 & 0.092631 & 7425 \\
\hline $\mathrm{KL}$ & 18.05 & 3 & 23 & 2.43 & 402 & 112.1 & 9.465021 & 2.9 & 0.011532 & 0.387101 & 22963 \\
\hline $\mathrm{C}_{22} \mathrm{~N}_{22}$ & 2.0 & 7 & 25 & 2.54 & 14 & 8.640 & 9.84252 & 1.8 & 0.049997 & 0.096159 & 6096 \\
\hline $\mathrm{MN}$ & 9.20 & 10 & 18 & 1.95 & 286 & 33.23 & 9.230769 & 2.7 & 0.028348 & 0.195943 & 8355 \\
\hline VU & 6.20 & 17 & 15 & 1.54 & 324 & 15.61 & 9.74026 & 1.9 & 0.01769 & 0.306163 & 9163 \\
\hline $\mathrm{C}_{13} \mathrm{~N}_{13}$ & 1.5 & 20 & 13 & 1.04 & 43 & 1.575 & 12.5 & 2.8 & 0.031574 & 0.181584 & 3016 \\
\hline $\mathrm{C}_{19} \mathrm{~N}_{19}$ & 1.0 & 28 & 12 & 1.59 & 58 & 0.833 & 7.54717 & 3.5 & 0.050163 & 0.126601 & 3975 \\
\hline $\mathrm{C}_{11} \mathrm{~N}_{11}$ & 1.05 & 37 & 12 & 2.51 & 74 & 0.675 & 4.780876 & 3.4 & 0.089231 & 0.08061 & 5020 \\
\hline $\mathrm{C}_{12} \mathrm{~N}_{12}$ & 1.00 & 38 & 10 & 1.34 & 56 & 0.405 & 7.462687 & 2.4 & 0.102287 & 0.066195 & 1608 \\
\hline $\mathrm{TS}$ & 3.40 & 20 & 10 & 2.94 & 125 & 4.523 & 3.401361 & 7.9 & 0.053347 & 0.147102 & 11613 \\
\hline $\mathrm{C}_{14} \mathrm{~N}_{14}$ & 1.00 & 30 & 9 & 1.52 & 49 & 0.607 & 5.921053 & 4.7 & 0.05018 & 0.121714 & 3572 \\
\hline $\mathrm{C}_{15} \mathrm{~N}_{15}$ & 1.00 & 39 & 10 & 1.02 & 43 & 0.585 & 9.803922 & 4.1 & 0.085143 & 0.066387 & 1071 \\
\hline $\mathrm{C}_{16} \mathrm{~N}_{16}$ & 1.35 & 28 & 15 & 1.72 & 27 & 0.923 & 8.72093 & 3.6 & 0.045733 & 0.136329 & 4816 \\
\hline $\mathrm{O}_{2} \mathrm{O}_{1}$ & 2.30 & 29 & 12 & 2.54 & 71 & 3.105 & 4.724409 & 2.5 & 0.042317 & 0.150248 & 9525 \\
\hline $\mathrm{C}_{18} \mathrm{~N}_{18}$ & 0.80 & 48 & 9 & 2.24 & 26 & 0.945 & 4.017857 & 7.6 & 0.082031 & 0.076797 & 4032 \\
\hline
\end{tabular}




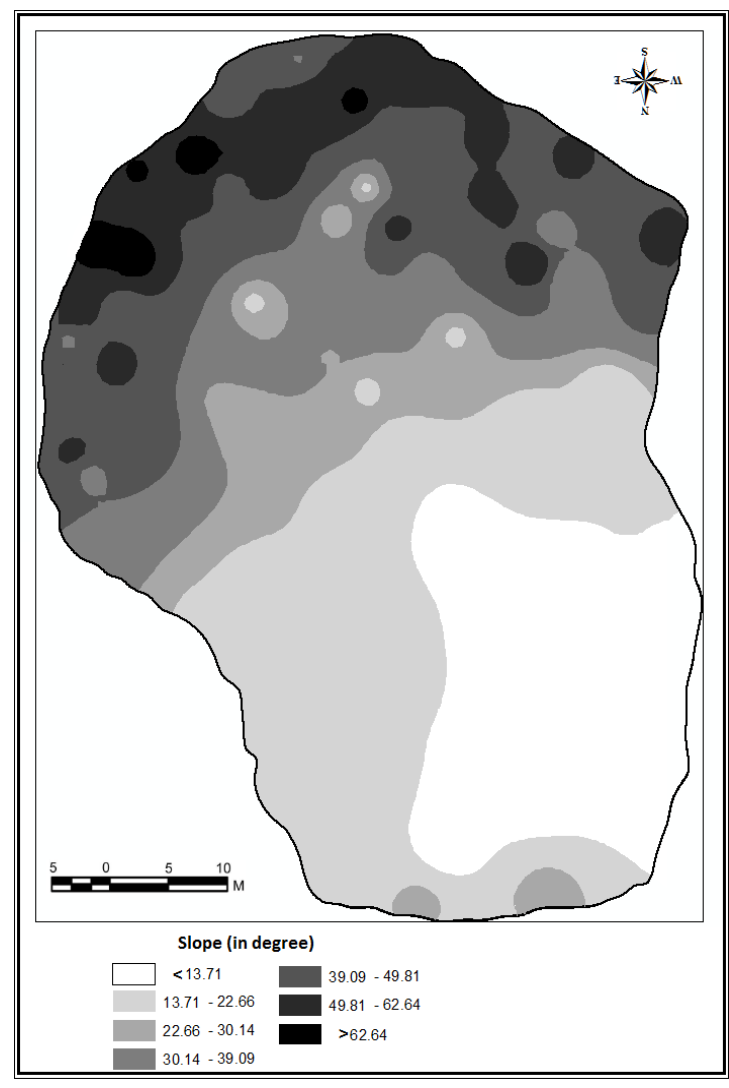

Figure 6. Slope map of the study area

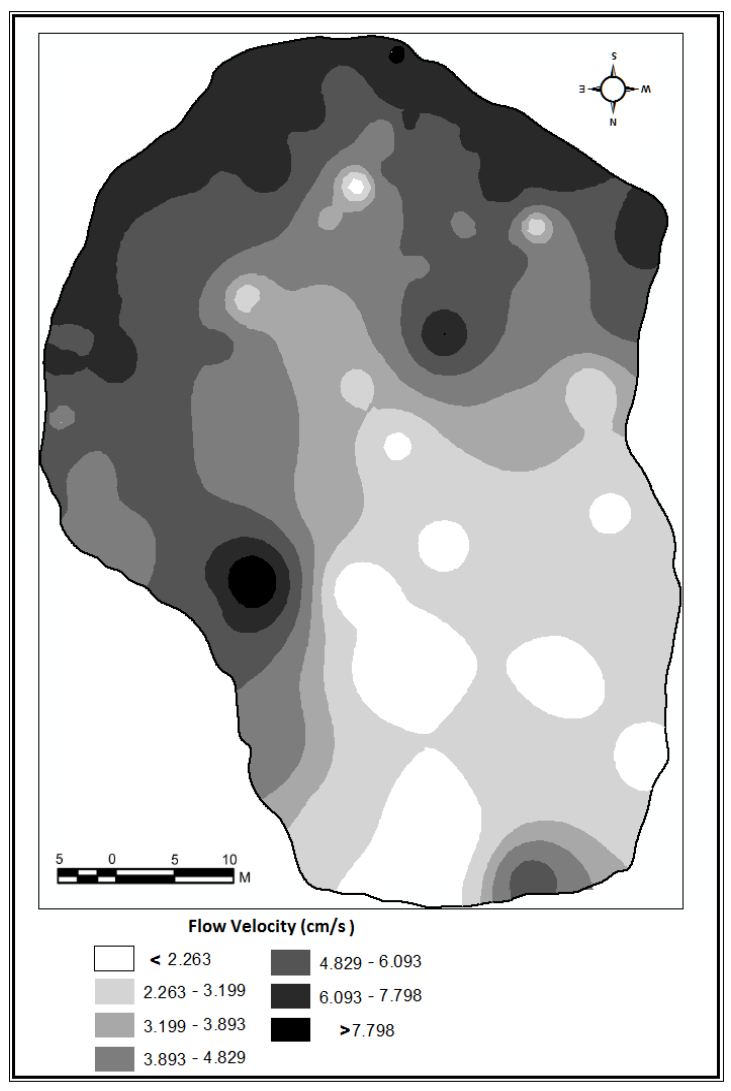

Figure 7. Spatial distribution of flow velocity of the study area

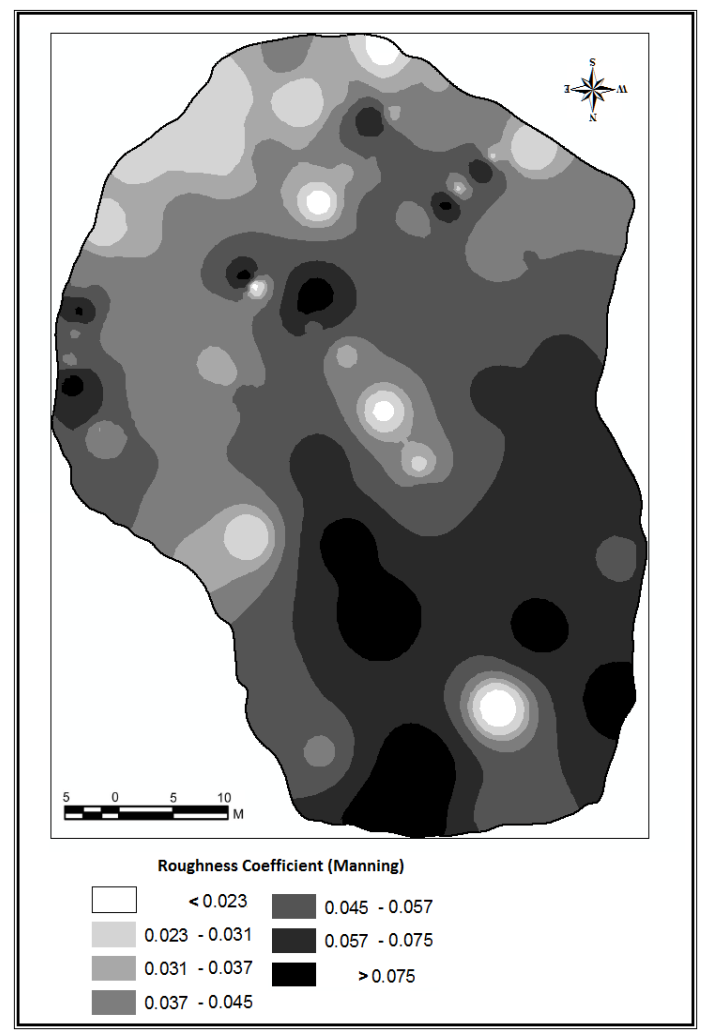

Figure 8. Spatial distribution of roughness coefficient (manning) of the study area 


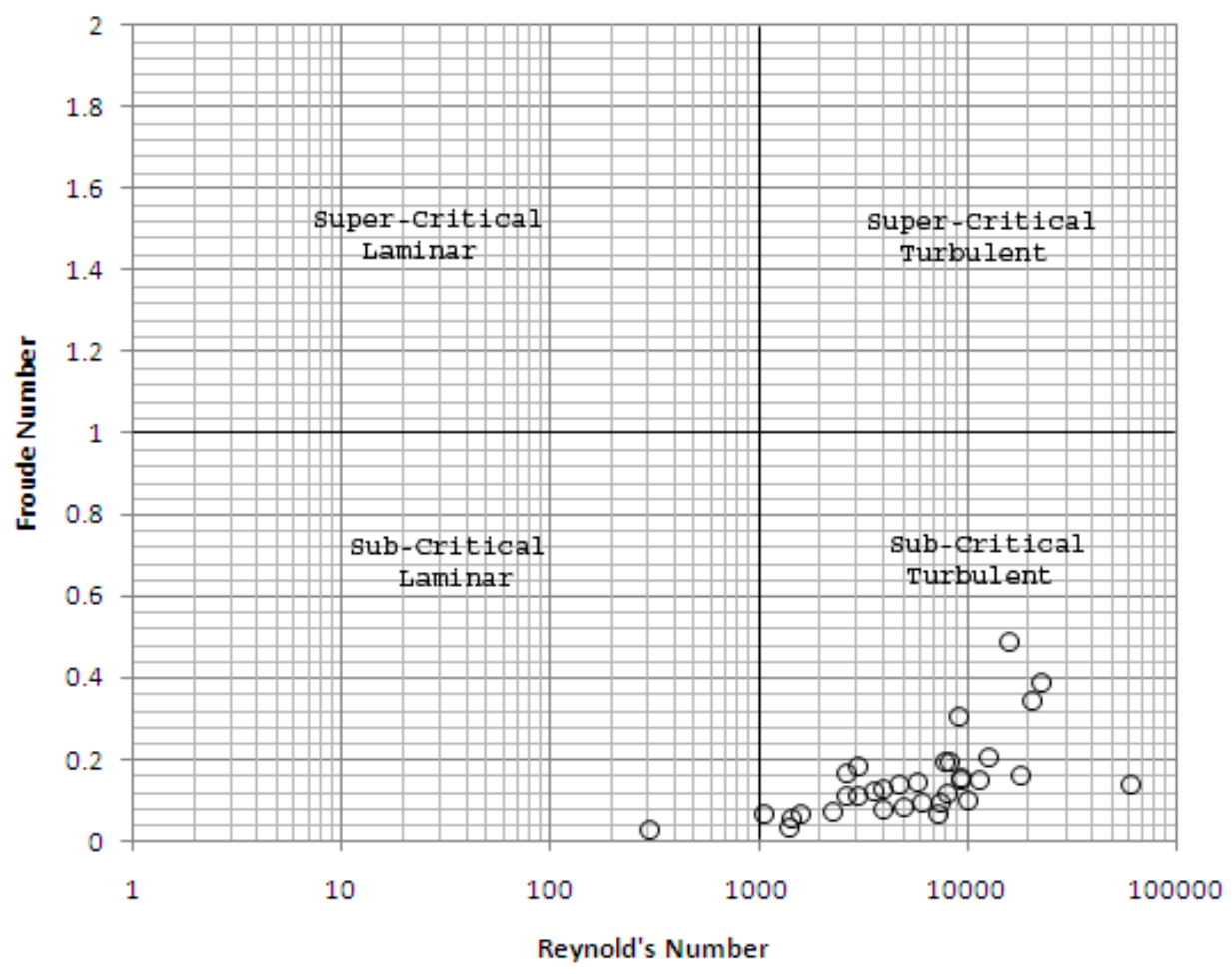

Figure 9. Hydraulic flow regimes for the experimental data

\section{Conclusions}

Process based models for predicting runoff and erosion on upland areas require information on flow hydraulics specially roughness coefficients. Dye tracing procedures were used in this study for precise monitoring of flow hydraulics channels. The velocity and flow channels of dye cloud led to some important understanding of processes acting in concerned area. Sub-critical turbulent flow in the channels is mainly controlled by hydraulic roughness. The ability to understand flow processes will improve the cognition of process-response system operating in gully system of lateritic uplands. Material transfer along the rills is not directly controlled by the slope, but by the hydraulic roughness, where gradient may be a factor but not the sole determinant. For predicting flow velocity, roughness coefficient (Manning) and material transfer had to be given more importance over gradient and other hydraulic variables of channels. The accurate monitoring and prediction of hydraulic roughness coefficients will improve our ability to understand and properly model upland flow hydraulics.

\section{References}

Abrahams, A. D., \& Parsons, A. J. (1994). Hydraulics of interrill overland flow on stone-covered desert surface. Catena, 23, 111-140. http://dx.doi.org/10.1016/0341-8162(94)90057-4

Abrahams, A. D., Parsons, A. J., \& Luk, S. H. (1986). Field measurement of the velocity of overland flow using dye tracing. Earth Surf. Process. Landforms, 11, 653-57. http://dx.doi.org/10.1002/esp.3290110608

Abrahams, A., \& Li, G. (1996). Rill Hydraulics on a semiarid hillslope, Southern Arizona. Earth Surface $\begin{array}{llll}\text { Processes } \quad \text { and } & \text { Landforms, }\end{array}$ http://dx.doi.org/10.1002/(SICI)1096-9837(199601)21:1<35::AID-ESP539>3.0.CO;2-T

Bryan, R. B., Govers, G., \& Poesen, J. (1989). The concept of soil erodibility and some problems of assessment and application. Catena, 16, 393-412. http://dx.doi.org/10.1016/0341-8162(89)90023-4

Bunte, K., \& Poesen, J. (1993). Effects of rock fragment covers on erosion and transport of noncohesive sediment by shallow overland flow. Water Resour. Res., 29, 1415-1424. http://dx.doi.org/10.1029/92WR02706

Chow, V. T. (1959). Open-channel hydraulics. New York: McGraw-Hill. 
Favis-Mortlock, D. T., Boardman, J., Parsons, A. J., \& Lascelles, B. (2000). Emergence and erosion: a model for rill initiation and development. Hydrol. Process., 14, 2173-2205. http://dx.doi.org/10.1002/1099-1085(20000815/30)14:11/12<2173::AID-HYP61>3.0.CO;2-6

Finkner, S. C., \& Gilley, J. E. (1988). Measurement of flow components on upland areas using dye dilution techniques. Transactions of the ASAE, 31(4), 1086-1091.

Foster, G. R., Huggins, L. F., \& Meyer, L. D. (1984). A laboratory study of rill hydraulics: I. Velocity relationships. Transactions of ASAE, 27, 790-796.

Gilley, J. E., Kottwitz, E. R., \& Simanton, J. R. (1990). Hydraulic characteristics of rills. Trans. ASAE, 33, 1900-1906.

Gilley, J. E., Kottwitz, E. R., \& Wieman, G. A. (1992). Dracy-Weishach roughness coefficients for gravel and $\begin{array}{llllll}\text { cobble surfaces. } \quad J . & \text { Irrig. }\end{array}$ http://dx.doi.org/10.1061/(ASCE)0733-9437(1992)118:1(104)

Gimenez, G., \& Govers, G. (2001). Interaction between bed roughness and flow hydraulics in eroding rills. Water Resources Research, 33(2), 349-358.

Giménez, G., \& Govers, G. (2002). Flow detachment by concentrated flow on smooth and irregular beds. Soil Science Society of America Journal, 66(5), 1475-1483. http://dx.doi.org/10.2136/sssaj2002.1475

Govers, G. (1991). Rill erosion on arable land in central Belgium: rates, controls and predictability. Catena, 18 , 133-155. http://dx.doi.org/10.1016/0341-8162(91)90013-N

Govers, G. (1992). Relation between discharge, velocity and flow area for rills eroding loose, non-layered materials. Earth Surface Processes and Landforms, 17, 515-528. http://dx.doi.org/10.1002/esp.3290170510

Govers, G., Giménez, R., \& Oost, KVan. (2007). Rill erosion: exploring the relationship between experiments, modelling and field observations. Earth Science Reviews, 84(3-4), 87-102. http://dx.doi.org/10.1016/j.earscirev.2007.06.001

Jehangir, M., \& Zokaib, S. (2000). Annual progress report - PARDYP (The People and Resource Dynamics in Mountain Watersheds of the HKH), Pakistan, International Centre for Integrated Mountain Development, Katmandu, Nepal.

Lei, T., Nearing, M. A., Haghighi, K., \& Bralts, V. F. (1998). Rill erosion and morphological evolution: a simulation model. Water Resour. Res., 34, 3157-3168. http://dx.doi.org/10.1029/98WR02162

Mancilla, G. A. (2001). Prediction of rill density, transport capacity and associated soil loss of different tillage systems under winter conditions. M.S. thesis, College of Engineering and Architecture, Washington State University.

Mancilla, G. A., Chen, S., \& McCool, D. K. (2005). Rill density prediction and flow velocity distribution on agricultural areas in the Pacific Northwest. Soil and Tillage Research, 84, 54-66. http://dx.doi.org/10.1016/j.still.2004.10.002

Nachtergaele, J., Poesen, J., Sidorchuk, A., \& Torri, D. (2002). Prediction of concentrated flow width in ephemeral gully channels. Hydrological Processes, 16, 1935-1953. http://dx.doi.org/10.1002/hyp.392

Nearing, M. A., Norton, L. D., Bulgakov, D. A., Larionov, G. A., West, L. T., \& Dontsova, K. M. (1997). Hydraulics and erosion in eroding rills. Water Resources Research, 33, 865-876. http://dx.doi.org/10.1029/97WR00013

Nearing, M. A., Simanton, J. R., Norton, L. D., Bulygin, S. J., \& Stone, J. (1999). Soil erosion by surface water flow on a stony, semi arid hillslope. Earth Surface Processes and Landforms, 24(8), 677-686. http://dx.doi.org/10.1002/(SICI)1096-9837(199908)24:8<677::AID-ESP981>3.0.CO;2-1

Obiechefu, G. C., \& Morgan, R. P. (1994). Rill initiation and evolution: a precursor for understanding gully erosion. American Society of Agricultural Engineers, 94, 2584-2599.

Poesen, J., Nachtergaele, J., Verstraeten, G., \& Valentina, C. (2003). Gully erosion and environmental change: importance and research needs. Catena, 50, 91-133. http://dx.doi.org/10.1016/S0341-8162(02)00143-1

Polyakov, V. O., \& Nearing, M. A. (2003). Sediment transport in rill flow under deposition and detachment conditions. Catena, 51, 33-43. http://dx.doi.org/10.1016/S0341-8162(02)00090-5 
Prosser, I. P., \& Dietrich, W. E. (1995). Field experiments on erosion by overland flow and their implications for a digital terrain model of channel initiation. Water Resour. Res., 31, 2867-2876. http://dx.doi.org/10.1029/95WR02218

Sanchis, M. P. S., Torri, D., Borselli, L., Bryan, R., Poesen, J., Yanez, M. S., \& Cremer, C. (2009). Estimating parameters of the channel width-flow discharge relation using rill and gully channel junction data. Earth Surf. Process and Landforms, 34(15), 2023-2030. http://dx.doi.org/10.1002/esp.1887

Savat, J. (1980). Resistance to flow in rough supercritical sheet flow. Earth Surf. Process. Landforms, 5, 103-122.

Savenije, H. H. G. (2003). The width of a bankfull channel; Lacey's formula explained. Journal of Hydrology, 276, 176-183. http://dx.doi.org/10.1016/S0022-1694(03)00069-6

Shit, P. K., \& Maiti, R. K. (2008). Rill Morphology in relation to Topographic Pedologic and Hydrologic attributes -- a case study at Rangamati, Paschim Medinipur, W.B. Indian Journal of Geography and Environment, 10, 63-75.

Slattery, M. C., \& Bryan, R. B. (1992). Hydraulic conditions for rill incision under simulated rainfall: a laboratory experiment. Earth Surf. Process. Landforms, 17, 127-146. $\mathrm{http}: / / \mathrm{dx}$. doi.org/10.1002/esp.3290170203

Strahler, A. N. (1964). Quantitative Geomorphology of Drainage Basins and Channel Networks, in Handbook of Applied Hydrology (editaed by V.T. Chow). New York: McGraw Hill Book Co. pp. 39-76.

Takken, I., \& Govers, G. (1998). Factors influencing the velocity- discharge relationship in rills. Modelling Soil Erosion Sediment Transport and Closely Related Hydrological Processes. (Proceeding of a symposium held at Vienna, July), IAHS, pp. 249.

Torri, D., Poesen, J., Borselli, L., \& Knapen, A. (2006). Channel width-flow discharge relationships for rills and gullies. Geomorphology, 76, 273-279. http://dx.doi.org/10.1016/j.geomorph.2005.11.010

Van Liew, M. W., \& Saxton, K. E. (1983). Slope steepness and incorporated residue effects on rill erosion. Trans. ASAE, 26, 1743.

Zokaib, S., Jehangir, M., Shah, H., Merz, J, \& White, R. (2005). Measurement and distribution of runoff and soil losses from selected watersheds in the Hindu-Kush Himalayan region. Aquatic Ecosystem Health \& Management, 8(3), 235-241. http://dx.doi.org/10.1080/14634980500234727 